\title{
STRUKTUR DAN KOMPOSISI TAMBAK TEKNOLOGI ULIR FILTER UNTUK PENINGKATAN PRODUKSI GARAM RAKYAT
}

\author{
Rikha Bramawanto1), Sophia L Sagala1), Ifan R Suhelmi"1) \& Hari Prihatno1) \\ ${ }^{1)}$ Pusat Penelitian dan Pengembangan Sumberdaya Laut dan Pesisir, Balitbang-KP, KKP
}

Diterima tanggal: 17 Januari 2015; Diterima setelah perbaikan: 11 Maret 2015; Disetujui terbit tanggal 9 Juni 2015

\begin{abstract}
ABSTRAK
Prinsip utama dalam pembuatan garam teknologi ulir filter (TUF) adalah evaporasi air laut dengan bantuan sinar matahari melalui pengaliran air pada petakan-petakan berseri dalam proses penuaannya dan penambahan material alam yang berperan sebagai filter. Tulisan ini bertujuan untuk mengkaji kondisi struktur dan komposisi lahan tambak garam TUF sebagai teknologi alternatif yang dapat meningkatkan produksi garam rakyat. Survei, pengukuran secara langsung, pengamatan fisik dan wawancara telah dilakukan di tambak garam rakyat di Desa Ambulu, Kecamatan Losari, Kabupaten Cirebon. Data dan hasil pengamatan yang diperoleh kemudian diolah menggunakan sistem informasi geografis dan dianalisis serta dibandingkan dengan literatur. Hasil penelitian menunjukkan bahwa pada tambak garam TUF dilakukan modifikasi lahan yaitu membuat petakan-petakan memanjang berseri dalam satu kolam kondenser (ulir) dan memperdalam kolam reservoir. Modifikasi pada kolam kondenser mempermudah petambak dalam mengendalikan aliran brine dan memantau kenaikan densitasnya. Diketahui juga bahwa percepatan evaporasi brine pada sistem ini diperoleh dengan menambah pematang tanah. Dari hasil perhitungan diperoleh bahwa pematang yang bersifat konduktor panas ini terdedah radiasi matahari sebesar $112 \%$ untuk ulir besar dan $135 \%$ untuk ulir kecil. Sedangkan modifikasi pada kolam reservoir menghasilkan efisiensi pemanfaatan lahan, dari proporsi $28 \%$ terhadap total luas tambak menjadi $75 \%$ terhadap total volume tambak. Perubahan struktur dan komposisi tersebut meningkatkan produksi garam hingga mencapai \pm 200 ton/ha per musim panen.
\end{abstract}

Kata kunci: struktur tambak, tekonologi ulir filter, produksi garam

\section{ABSTRACT}

Two main principles in salt processing using filtering - threaded technology (TUF system)are seawater evaporation through a series of shallow channels to condense seawater into brine and the use of natural filtering membranes to purify the water. The present study was aimed to get insight on the structure and compositions of modified salt pan as an alternative technology that could contribute to improve the salt production. A survey, a direct measurement, physical obsevations and interviews were conducted in salt ponds with filtering-threaded technique. The measurements and observations were done in salt ponds located at Ambulu Village, Losari District, Cirebon Regency, West Java. Data collected were analyzed using Geographycal Information System and compared with literatures through a desk study. The results showed that salt production derived from the present method could be up to \pm 200 ton/ha during dry season. In Filtering-Threaded-Techology System, land was modified by making a serial of elongated ponds in the condensers and by deepen the reservoir. Modifiying the condensers into elongated ponds facilitated salt farmers to controll brine flows and monitor brine density rise. The result also showed that the addition of dikes in condenser system could accelerate brine evaporation as they could store heat from solar radiation exposure. The areas exposed by solar radiation increased by the addition of dikes, i.e. $112 \%$ for large threaded pans and $135 \%$ for small threadedpans. Moreover, modification in reservoir enhanced land use efficiency, i.e. from $28 \%$ of the total saltern area to $75 \%$ of the total saltern volume. It can be concluded that salt production obtained from the present technology was increased up to \pm 200 ton/ha during dry season.

\section{Keywords: saltpan structures, TUF system, salt production}

\section{PENDAHULUAN}

Garam menjadi kebutuhan esensial bagi kehidupan manusia dan semakin dibutuhkan dalam berbagai proses industri. Kebutuhan terhadap jenis dan kebutuhan garam semakin meningkat, mulai dari keperluan industri kimia (CAP), rumah tangga, cairan infus, farmasi, kosmetik, industri aneka pangan/minum hingga pengasinan ikan. (Departemen Perindustrian, 2009). Kebutuhan tersebut belum diikuti dengan kuantitas dan kualitas produksi garam nasional yang memadai.

Data dari Sekretariat Pemberdayaan Usaha Garam Rakyat PUGAR Kementerian Kelautan dan
Perikanan (2012 dan 2013) menyatakan kuantitas produksi garam rakyat pada tahun 2011, 2012 dan 2013 berturut-turut sebanyak \pm 850 ribu ton, \pm 2 juta ton dan $\pm 1,3$ juta ton. Pada tahun 2014 Kementerian Kelautan dan Perikanan menargetkan produksi garam sebesar 3,3 juta ton (KKP, 2014), sedangkan kebutuhan garam konsumsi nasional hanya sebesar 1,5 juta ton per tahun. Oleh karena itu, perlu strategi untuk mengalihkan sebagian produksi garam rakyat untuk kebutuhan konsumsi menjadi kebutuhan industri dengan konsekuensi melakukan peningkatan kualitas garam.

Kualitas garam rakyat dapat ditingkatkan melalui intensifikasi tambak. Penerapan teknologi menuju 
intensifikasi yang telah diperkenalkan kepada masyarakat antara lain adalah penggunaan ramsol, penggunaan membrane atau terpal sebagai dasar meja kristalisasi, serta penerapan teknologi ulir yang disempurnakan menjadi teknologi ulir filter (TUF). Masing-masing teknologi memiliki kendala. Sebagai contoh penggunaan bahan ramsol hanya dapat memutihkan kristal garam (Kadarwati, et al, 2010) dan diperlukan biaya untuk pengadaan ramsol. Penggunaan geomembran membutuhkan biaya yang cukup tinggi, sementara penggunaan terpal sebagai alternatif memiliki masa pakai cukup pendek. Berbeda halnya dari teknologi disebutkan di atas, TUF membutuhkan perubahan struktur tambak menjadi sistem ulir. Beberapa hal tersebut menyebabkan petambak cenderung sulit menerima penerapan teknologi tersebut.

TUF merupakan suatu teknik pembuatan garam yang dikembangkan oleh seorang petambak garam bernama $H$. Sanusi. Prinsip utama dalam teknik pembuatan garam ini adalah evaporasi air laut dengan bantuan sinar matahari dialirkan melalui petakanpetakan berseri dalam proses penuaannya. Selain itu, ditambahkan material alam yang digunakan sebagai filter untuk purifikasi air tua. TUF merupakan alternatif intensifikasi yang paling diminati dikarenakan oleh prospek kuantitas dan kualitas garam yang dihasilkan. Produktivitas sistem TUF ini dapat mencapai 336 ton/ $\mathrm{Ha}$ /musim. Namun, jika pelaksanaan tersebut meleset setidaknya produksi 120 ton/Ha/musim dapat dicapai (Kurniawan \& Erlina, 2012).

Difusi teknologi TUF juga mengalami perkembangan yang cukup pesat. Hal ini didukung dengan program pemerintah melalui program PUGAR, salah satunya dengan melaksanakan kegiatan "Fasilitasi Peningkatan Produksi (Demplot) TUF" di 30 Kabupaten/Kota, dimana 29 Kabupaten/Kota akan mengimplementasikan TUF pada tahun 2014. Sejumlah demplot TUF akan diaplikasikan dan dipergunakan sebagai sarana pembelajaran yang efisien dan efektif (Dirjen KP3K-KKP, 2014).

Informasi tentang peningkatan kuantitas dan kualitas produksi garam menggunakan TUF telah banyak dilaporkan (Kurniawan \& Erlina, 2012; Dirjen KP3K-KKP, 2014; Bramawanto et al., 2014). Namun kajian ilmiah terhadap struktur dan komposisi tambak yang menentukan peningkatan produktifitas masih perlu dilakukan secara mendalam. Tujuan penelitian ini adalah untuk memberikan informasi ilmiah tentang kondisi lahan pada tambak garam TUF sebagai teknologi alternatif yang dapat meningkatkan produksi garam rakyat. Informasi tersebut selanjutnya dapat dipergunakan untuk menyempurnakan teknologi yang telah ada.

\section{METODE PENELITIAN}

Penelitian lapangan dilakukan pada tanggal 25 29 Agustus 2014 di tambak garam milik petambak $\mathrm{H}$. Sanusi yang berada di desa Ambulu, Kecamatan Losari, Kabupaten Cirebon. Tambak garam tersebut berada pada posisi geografis 6048,771 - 6048,979 Lintang Selatan dan 108048,748 - 108048,904 Bujur Timur (Gambar 1).

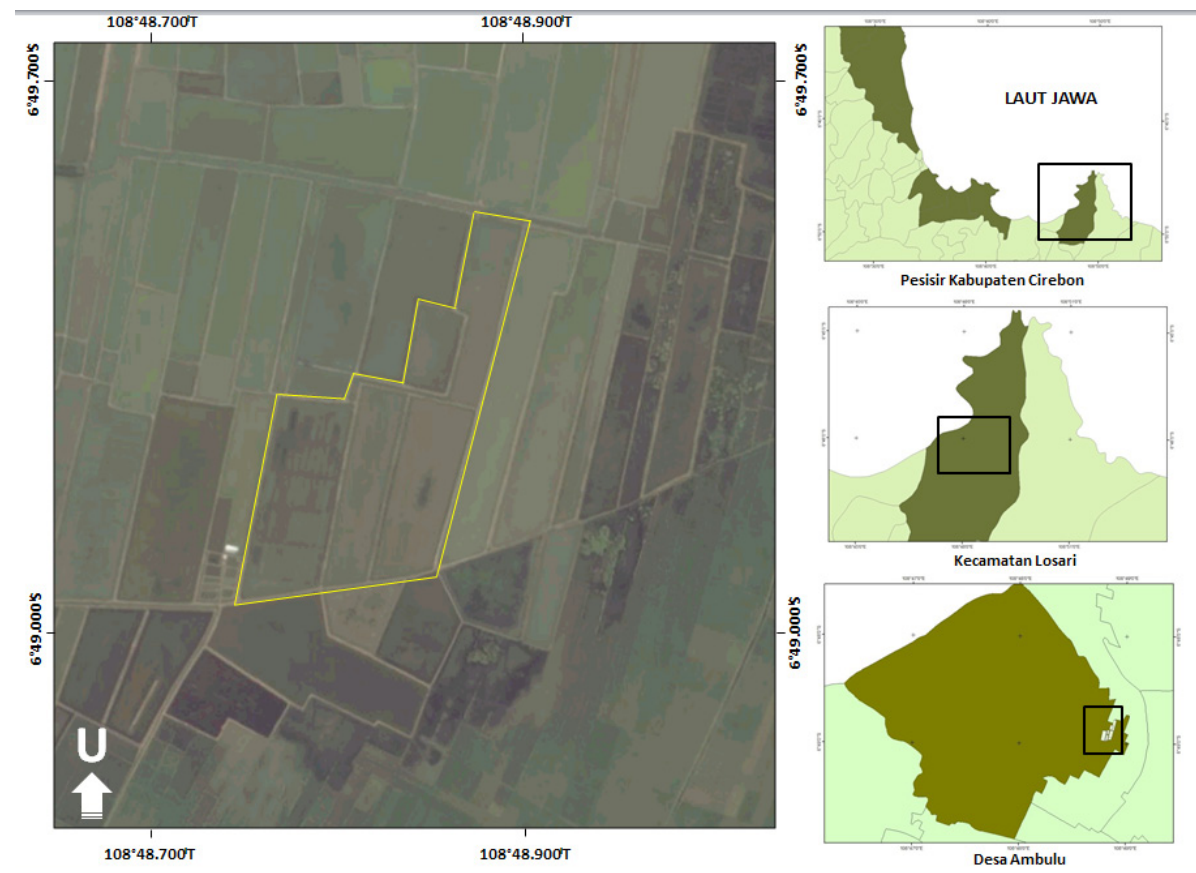

Gambar 1. Peta Lokasi Penelitian Tambak Garam TUF di Desa Ambulu Kecamatan Losari Kabupaten Cirebon (milik petambak H. Sanusi). 
Survei yang dilakukan mencakup kegiatan pengukuran suhu air/brine dan suhu udara, pengamatan fisik dan wawancara. Pengamatan fisik dilakukan untuk menginventarisasi luasan lahan, mengukur petakan-petakan, pematang sebagai penyusun komposisi tambak tersebut, dan menghimpun informasi mengenai kondisi di sekitar tambak yang berpeluang mempengaruhi proses pembuatan garam. Posisi geografis dari lokasi dan titik petakan/kolam pengamatan diperoleh dengan menggunakan global positioning system (GPS) seri Oregon 550. Informasi prosedur pembuatan garam TUF dan pengelolaan brinenya diperoleh melalui wawancara terhadap lima petambak TUF dan observasi lapangan.

Visualisasi sebaran jenis petakan, komposisi dan struktur tambak TUF dilakukan melalui interpretasi citra satelit yang diperoleh dari Google Earth, dianalisa menggunakan sistem informasi geografis (SIG), kemudian hasilnya dibandingkan dengan literatur. Data yang diperoleh digunakan untuk menentukan komposisi dua dimensi melalui perhitungan proporsi luas dan komposisi tiga dimensi melalui perhitungan volume kolam brine pada setiap jenis kolam. Penghitungan luas kolam dilakukan setelah data titik koordinat masing-masing jenis kolam pada tambak diplot pada peta, kemudian dihitung masing-masing luasnya menggunakan perangkat lunak pengolah data SIG. Volume kolam-kolam dihitung dan diasoisasikan dengan ketersediaan brine pada tiap kolam. Analisis transfer energi panas pada struktur tambak yang dimodifikasi untuk mempercepat proses evaporasi brine, dilakukan dengan memperhatikan karakter suhu udara, air tua (brine) dan tanah di tambak.

\section{HASIL DAN PEMBAHASAN}

\section{Struktur Tambak Garam Teknologi Ulir Filter (TUF)}

Teknologi Ulir Filter merupakan sistem pengelolaan tambak yang dititikberatkan pada modifikasi lahan tambak dan kontrol kualitas air laut menjadi air tua (brine). Struktur dan komposisi tambak garam TUF ditampilkan pada Gambar 2. Terlihat pada Gambar 2 bahwa tambak garam TUF tersusun dari 3 komponen utama, yaitu dua kolam penampungan (reservoir), dua kolam peminihan (condenser) dan tiga kolam kristalisasi (crytallizers) yang dilengkapi dengan kanal brine (pre-crystallizers) dan pematangpematang.

Adapun fungsi masing-masing kolam tersebut adalah sebagai berikut:

- Kolam penampungan (reservoir) atau disebut juga waduk, embung, bozeem berfungsi sebagai tempat awal untuk menampung air laut dengan kadar kepekatan $1-5^{\circ}$ Be dan mengendapkan material organik.

- Kolam peminihan (condenser) merupakan petakan-petakan (kolam) tempat proses penuaan air laut dengan evaporasi sinar matahari. Pada

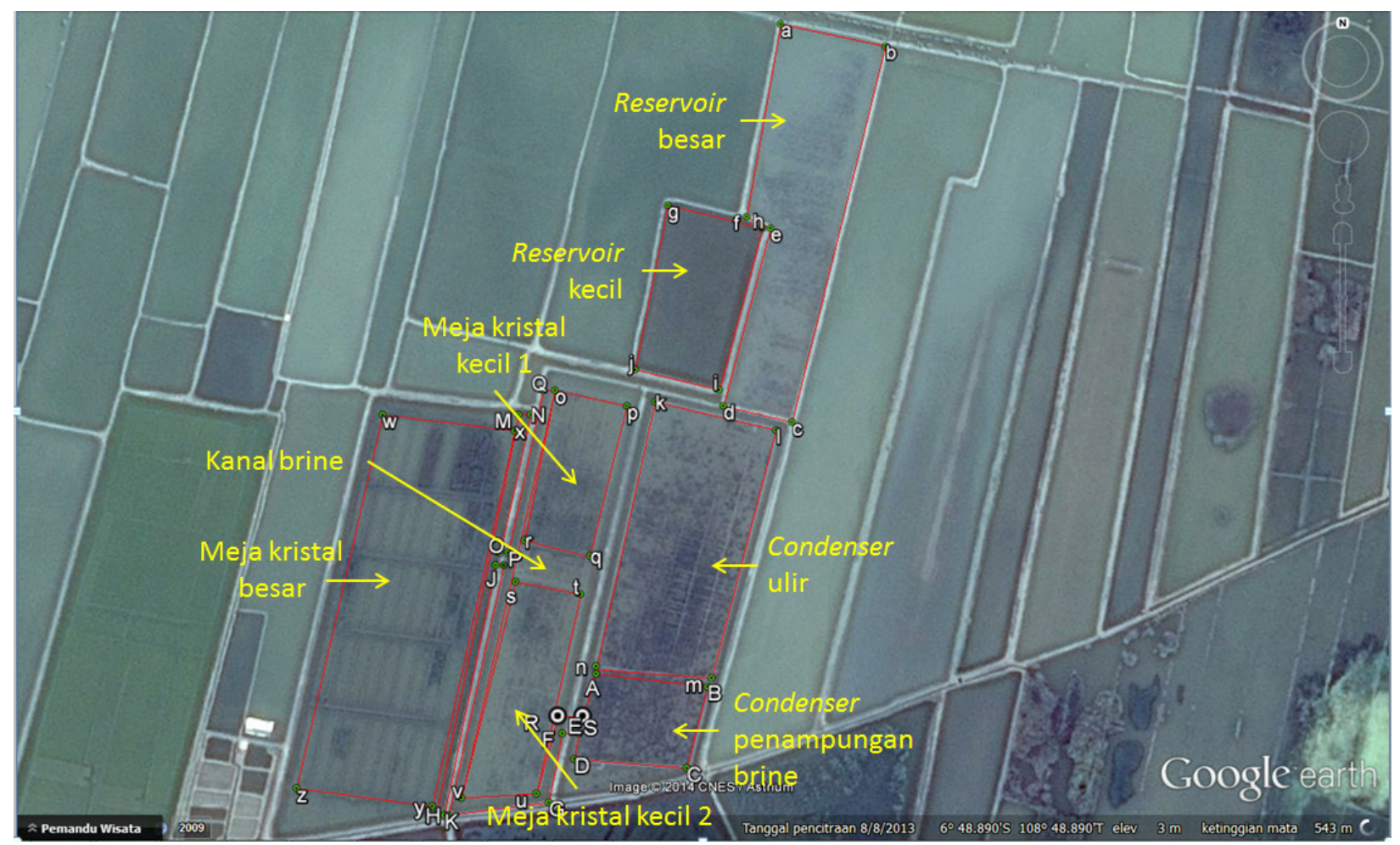

Gambar 2. Struktur Tambak Garam Teknologi Ulir Filter. 
sistem TUF, kolam peminihan ini dibuat dalam bentuk petakan-petakan berseri (ulir) semacam saluran berukuran seragam dengan lebar tidak lebih dari $3 \mathrm{~m}$. Pada kolam peminihan ini berlangsung penuaan air laut dari kepekatan 5 sampai menjadi kepakatan $25^{\circ} \mathrm{Be}$. Air tua (brine) dengan kepekatan $25^{\circ} \mathrm{Be}$ merupakan bahan baku garam yang akan dialirkan ke dalam meja kristal (crytalizers).

- Kanal Brine (pre-crystalizer) merupakan saluran kecil dan petakan tempat menampung brine densitas $25^{\circ}$ Be yang siap dikristalkan.

- Meja kristalisasi (crystalizers) merupakan petakan-petakan dimana terjadi kristalisasi brine menjadi kristal garam.

Pada kolam peminihan tambak garam TUF, terdapat petakan-petakan kecil memanjang yang saling terhubung secara berseri atau lebih dikenal dengan kolam ulir. Modifikasi lahan ini yang membedakan tambak garam TUF dengan tambak garam konvensional (Gambar 3). Pada beberapa tambak garam konvensional lainnya di Madura, ditemukan struktur tambak yang memiliki saluran serupa dengan kolam ulir yang mengelilingi sisi terluar tambak. Namun perbedaannya, saluran pada

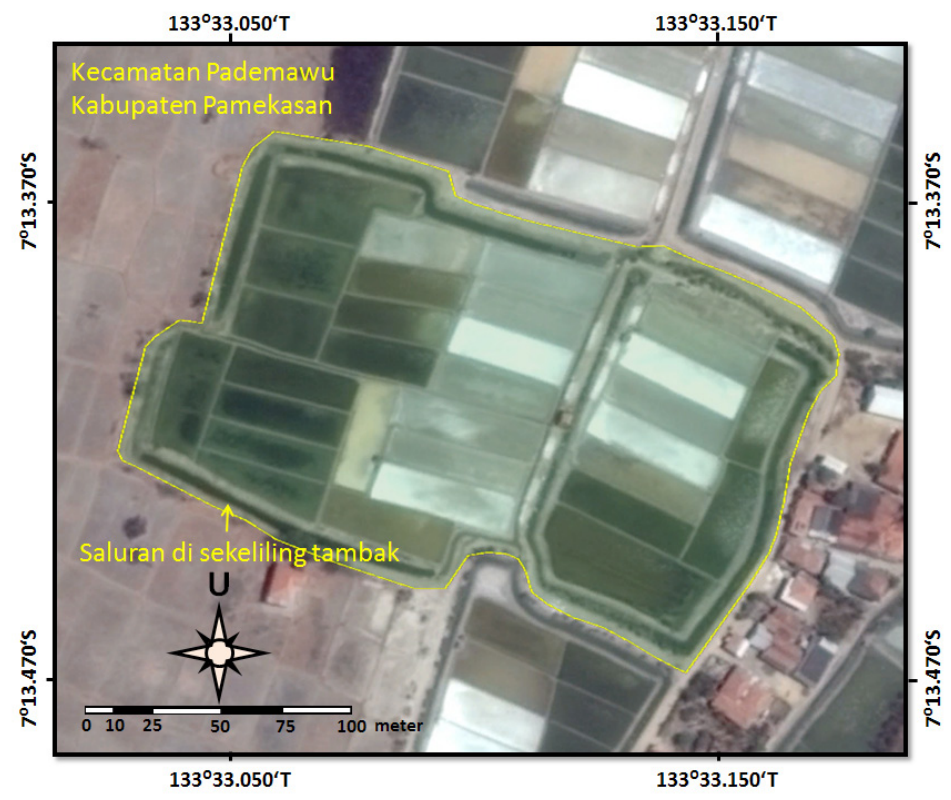

(a)

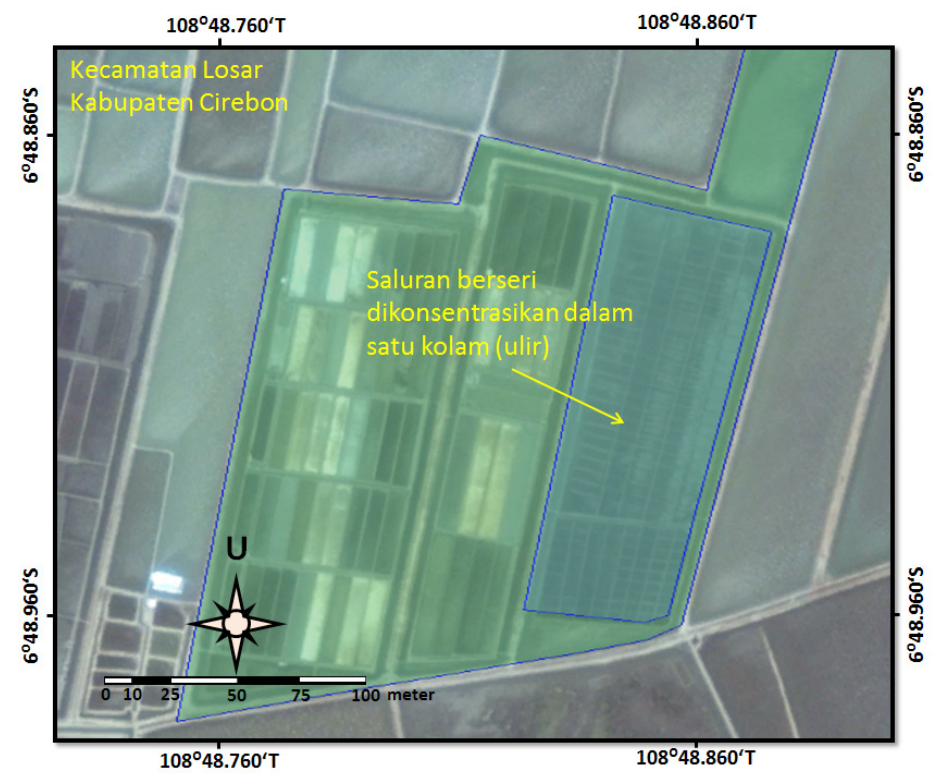

(b)

Gambar 3. Perbandingan saluran brine pada tambak garam konvensional (a) dan tambak garam TUF (b). 
sistem TUF dikonsentrasikan dalam satu kolam untuk memudahkan pengendalian aliran brine dan pemantauan kenaikan densitasnya. Pada prinsipnya, penggunaan saluran pada tambak konvensional maupun kolam ulir pada tambak TUF bertujuan untuk mempercepat proses penguapan sehingga dapat meningkatkan kuantitas produksi garam.

\section{Rasio Komposisi Kolam-kolam dalam Tambak Garam TUF}

Rasio antara reservoir, kolam peminihan dan meja kristalisasi ditinjau dari dua aspek yaitu luas area dan volume brine. Aspek luas area memperhatikan komposisi dua dimensi masing-masing kolam untuk melihat luas masing-masing jenis kolam. Sedangkan komposisi tiga dimensi dilakukan untuk melihat volume dan ketersediaan brine selama musim panas sehingga dapat menjaga kontinuitas keberlangsungan produksi garam secara optimal.
Pada Gambar 4 terlihat pembagian lahan terdiri dari 7 poligon. Poligon-poligon tersebut adalah kolam penampungan (reservoir) besar dan kecil, kolam peminihan (condenser) ulir, peminihan penampung dan saluran (kanal) brine, serta 3 meja kristalisasi (crystalization 1,2,3). Hasil penghitungan luas kolam penampungan, kolam peminihan dan meja kristal disajikan dalam Tabel 1. Data tersebut dipergunakan untuk menghitung rasio luas antar jenis kolam.

Berdasarkan perhitungan terlihat bahwa perbandingan luas antara kolam penampungan, kolam peminihan dan meja kristal adalah 25\% : 25\% : 50\% atau setara dengan 1: 1: 2 (Tabel 2). Rasio tersebut berbeda dengan standar perbandingan luas kolam penampungan/waduk : peminihan : meja garam di Korea, yaitu 55\% : 30\% : 15\% (Adiyoso et al, 2014), tambak garam berukuran kecil di Vietnam yaitu $40 \%$ : 40\% : 20\% dan tambak garam berukuran besar di Mesir yaitu 61\% : 26\% : 13\% (Baert et al., 2000).

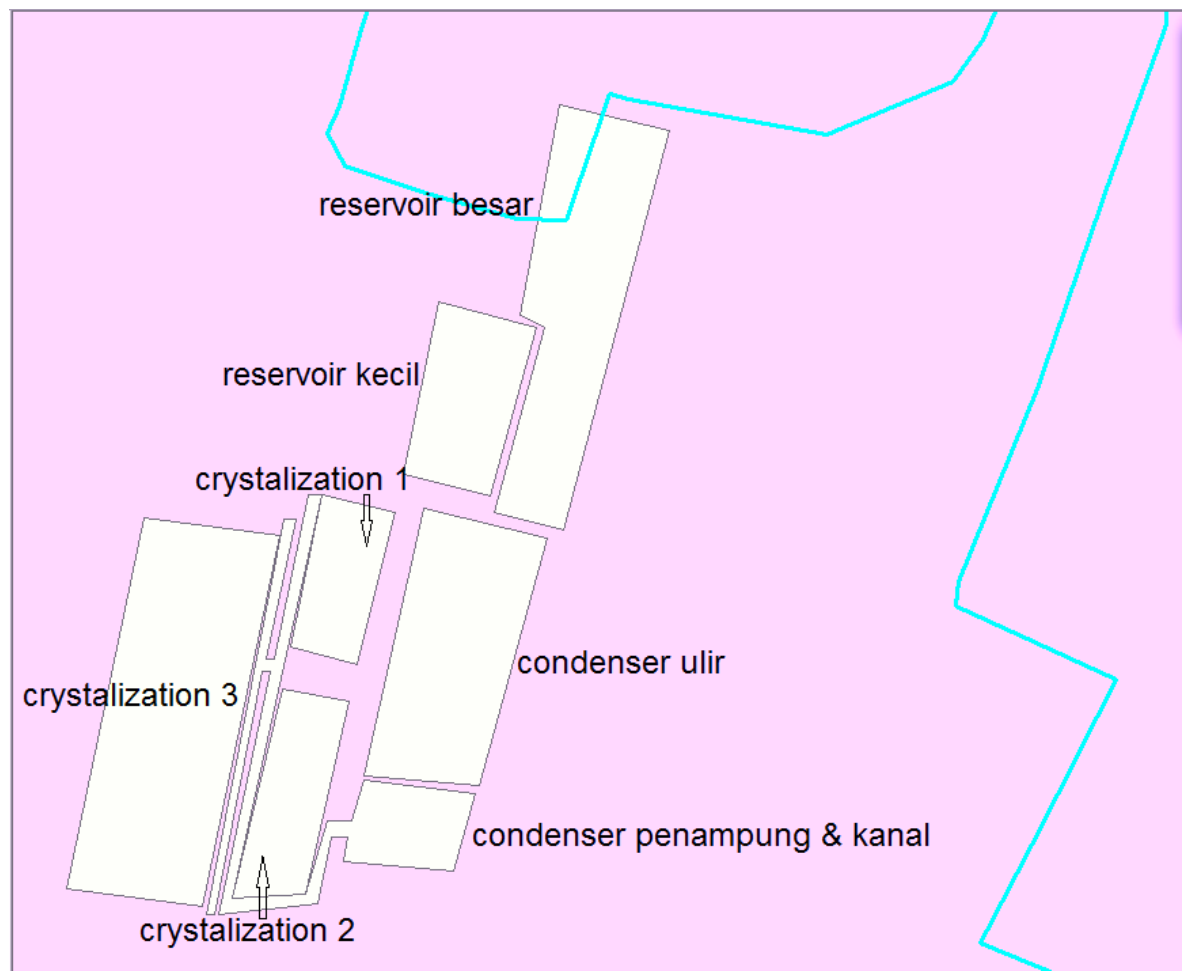

Gambar 4. Poligon-poligon berdasarkan jenis kolam pada tambak garam TUF.

Tabel 1.

Hasil pengukuran poligon pada Gambar 4

\begin{tabular}{|c|c|c|}
\hline Nomor Poligon & Luas Poligon (m²) & Keterangan \\
\hline Poligon 1 & $7.381,58$ & resevoir besar \\
\hline Poligon 2 & $3.361,22$ & reservoir kecil \\
\hline Poligon 3 & $6.406,87$ & condenser ulir \\
\hline Poligon 4 & $2.252,63$ & crystalization 1 \\
\hline Poligon 5 & $2.876,28$ & crystalization 2 \\
\hline Poligon 6 & $10.366,85$ & crystalization 3 \\
\hline Poligon 7 & $3.924,21$ & condenser penampung \& kanal \\
\hline
\end{tabular}


Tabel 2.

Rasio komposisi luas dan volume per jenis bak pada tambak garam TUF

\begin{tabular}{|c|c|c|c|c|c|c|c|c|c|}
\hline Jenis & ${ }^{0} \mathrm{Be}$ & $\begin{array}{c}\text { Nama } \\
\text { Poligon }\end{array}$ & $\begin{array}{l}\text { Luas } \\
\left(\mathrm{m}^{2}\right)\end{array}$ & $\begin{array}{l}\text { Luas per } \\
\text { jenis }\end{array}$ & Rasio & $\begin{array}{c}\text { Tinggi } \\
\text { brine } \\
\text { (m) }\end{array}$ & $\begin{array}{c}\text { Volume } \\
\left(\mathrm{m}^{3}\right)\end{array}$ & $\begin{array}{c}\text { Volume } \\
\text { per jenis }\end{array}$ & Rasio \\
\hline $\begin{array}{l}\text { Kolam } \\
\text { Penampungan }\end{array}$ & $1-5$ & $\begin{array}{l}\text { Reservoir } \\
\text { besar } \\
\text { Reservoir } \\
\text { kecil }\end{array}$ & $\begin{array}{l}7.500 \\
3.500\end{array}$ & 11.000 & 1 & $\begin{array}{l}1,0 \\
1,0\end{array}$ & $\begin{array}{l}7.500 \\
3.500\end{array}$ & 11.000 & 7 \\
\hline $\begin{array}{l}\text { Kolam } \\
\text { Peminihan }\end{array}$ & $5-25$ & $\begin{array}{l}\text { Kondenser } \\
\text { ulir } \\
\text { Kondenser } \\
\text { penampung } \\
\text { brine } \\
\text { Saluran } \\
\text { (kanal) }\end{array}$ & $\begin{array}{l}2.500 \\
2.000\end{array}$ & 11.000 & 1 & $0,07^{*}$ & $\begin{array}{r}1.250 \\
400\end{array}$ & 2.105 & 1 \\
\hline $\begin{array}{l}\text { Kolam } \\
\text { Kristalisasi }\end{array}$ & $25-27$ & $\begin{array}{l}\text { Meja } \\
\text { Kristalisasi } 1 \\
\text { Meja } \\
\text { Kristalisasi } 2 \\
\text { Meja } \\
\text { Kristalisasi } 3\end{array}$ & $\begin{array}{r}2.500 \\
3.000 \\
11.000\end{array}$ & 16.500 & 2 & $\begin{array}{l}0,1^{\star} \\
0,1^{*}\end{array}$ & $\begin{array}{r}250 \\
300 \\
1.100\end{array}$ & 1.650 & 1 \\
\hline
\end{tabular}

*Level (tinggi) air tua/brine tertinggi yang dialirkan ke dalam kolam

Sedangkan, aspek volume brine ditentukan melalui komposisi tiga dimensi, yaitu dengan menghitung volume masing-masing jenis kolam berdasarkan informasi berikut:

- Ketinggian air dalam kolam penampungan adalah sekitar $70-100 \mathrm{~cm}$;

- Ketinggian air yang diisikan kedalam kolam peminihan (ulir) adalah 5 sampai $7 \mathrm{~cm}$;

- Ketinggian kolam penampungan air tua (brine) setelah air melalui kolam ulir adalah $50 \mathrm{~cm}$

- Ketinggian air tua pada saluran dan kolam precrystal adalah $20 \mathrm{~cm}$;

- Air tua (brine) yang mencapai tingkat kepekatan $25^{\circ}$ Be dimasukkan ke dalam meja kristalisasi dengan tinggi $7-10 \mathrm{~cm}$.

Data tersebut digunakan untuk menghitung volume masing-masing kolam. Rasio volume kolam sekaligus menggambarkan ketersediaan brine sebagai

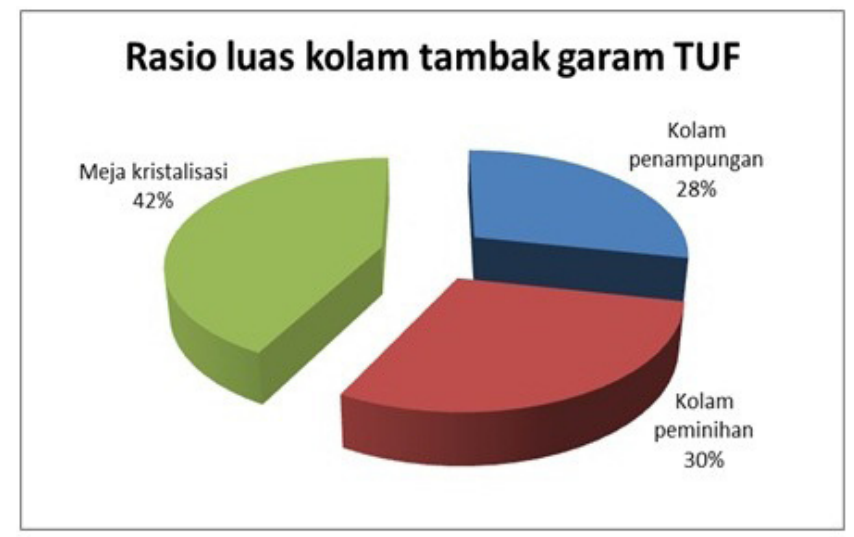

(a) bahan baku garam dengan perbandingan Kolam penampungan : Kolam peminihan : Meja kristalisasi adalah $75 \%: 14 \%: 11 \%$.

Efisiensi penggunaan lahan terlihat pada kolam penampungan (reservoir). Luas kolam yang mendapatkan porsi $28 \%$ dari seluruh luas kolam (Gambar 5a) dioptimalkan menjadi $75 \%$ volume kolam (Gambar 5b). Cara yang dilakukan adalah memperdalam kolam sehingga dengan luas 11.000 $\mathrm{m}^{2}$ dapat menampung brine sebanyak $11.000 \mathrm{~m}^{3}$. Hal tersebut dapat dilakukan mengingat kolam penampungan hanya berfungsi sebagai tempat menyimpan brine "muda" dan mengendapkan material organik yang terkandung di dalamnya. Sebagai perbandingan kolam peminihan yang juga memiliki luas $11.000 \mathrm{~m}^{2}$ dibuat hanya untuk menampung brine sebanyak $2.105 \mathrm{~m}^{3}$ (Tabel 1 dan Gambar 5).

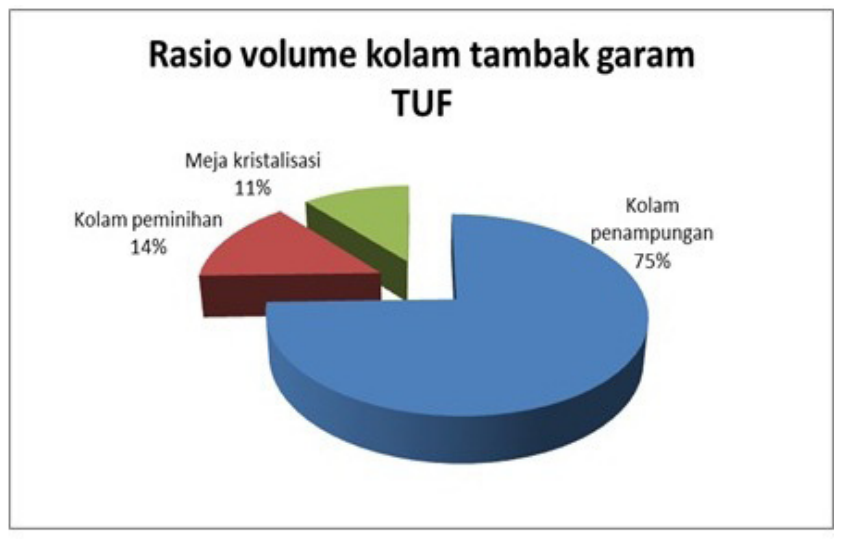

(b)

Gambar 5. Perbandingan rasio luas kolam (a) dan volume kolam (b) pada tambak garam TUF. 


\section{Konstruksi Tambak TUF}

Konstruksi tambak garam di Indonesia pada umumnya mengunakan konstruksi tangga (getrapte) dan konstruksi kompleks meja (tafel complex) (Purbani, 2001). Konstruksi tangga terdiri dari peminihanpeminihan dan meja-meja garam dengan konstruksi tangga yang teratur sehingga aliran air berjalan secara alamiah (gravitasi). Konstruksi kompleks meja terdiri dari kelompok-kelompok peminihan dan meja garam yang tidak teratur.

Konstruksi Tambak TUF memiliki karakter yang sedikit berbeda dibandingkan dengan kedua konstruksi tersebut. Selain susunannya yang kurang teratur karena menyesuaikan tambak disekitarnya (Gambar 3b dan 4) tambak TUF juga tidak sepenuhnya menggunakan konstruksi tangga, namun hanya pada beberapa strukturnya saja, terutama pada kolam ulir (kondenser) yang dibuat dengan kemiringan 1 - 2 derajat, dan pengaliran brine secara gravitasi dari kondenser ke tempat penampungan brine, sebagaimana tampak pada layout dan potongan melintang konstruksi tambak TUF yang ditampilkan dalam ilustrasi sederhana (Gambar 6).

\section{Sistem kondenser bertahap tambak garam TUF}

Terlihat pada Tabel 1 volume tertinggi terdapat pada kolam penampungan brine dengan densitas $1-5 \%$. Hal ini berlangsung pada awal persiapan lahan yang dilakukan pada awal musim kemarau, karena panas matahari pada saat itu belum begitu tinggi. Ketika penampungan air laut sebagai bahan baku pembuatan garam telah cukup banyak dan terjaga ketersediannya pada sekitar pertengahan musim kemarau sebagian kolam penampungan dapat diubah fungsinya menjadi kolam peminihan dalam bentuk ulir besar untuk meningkatkan suplai brine dengan densitas 5-10 ${ }^{\circ}$ Be (Gambar 7). Jika dilakukan perhitungan luas area pemanfaatan lahan reservoir sebagai kolam ulir besar terhadap kolam reservoir keseluruhan sebesar $55 \%$.

Teknik ulir filter menerapkan sistem bertahap pada proses penuaan air laut dengan membagi sistem ulir menjadi 2 (dua): sistem ulir besar dan sistem ulir kecil dengan perbandingan ukuran lebar penampang masing-masing $3 \mathrm{~m}$ dan $1 \mathrm{~m}$, dan kedalaman antara 15 dan $20 \mathrm{~cm}$. Sistem ulir besar dapat dibuat pada dua petakan dengan luas sekitar $3.700 \mathrm{~m}^{2}$ dan $2.350 \mathrm{~m}^{2}$ melalui penambahan pematang/pembuatan parit-parit setinggi $\pm 20 \mathrm{~cm}$. Dalam kolam A dan B masing-masing ditambahkan 24 dan 22 pematang tegak lurus pada sisi panjangnya, sehingga didapatkan penambahan luas penampang bidang evaporasi menjadi seluas sekitar $4.150 \mathrm{~m}^{2}$ dan $2.600 \mathrm{~m}^{2}$. Jika dihitung penambahan luas penampang evaporasi oleh ulir besar (baik kolam A maupun kolam B), diperoleh rerata penambahan luas penampang ulir besar sebesar $112 \%$. Sedangkan sistem ulir kecil dibuat pada lahan seluas sekitar 6.450 $\mathrm{m}^{2}$ dan ditambahkan sebanyak 97 pematang tegak lurus sisi panjang kolam dan 2 pematang pada sisi lebar kolam sehingga didapatkan penambahan luas penampang bidang evaporasi menjadi seluas 8.750

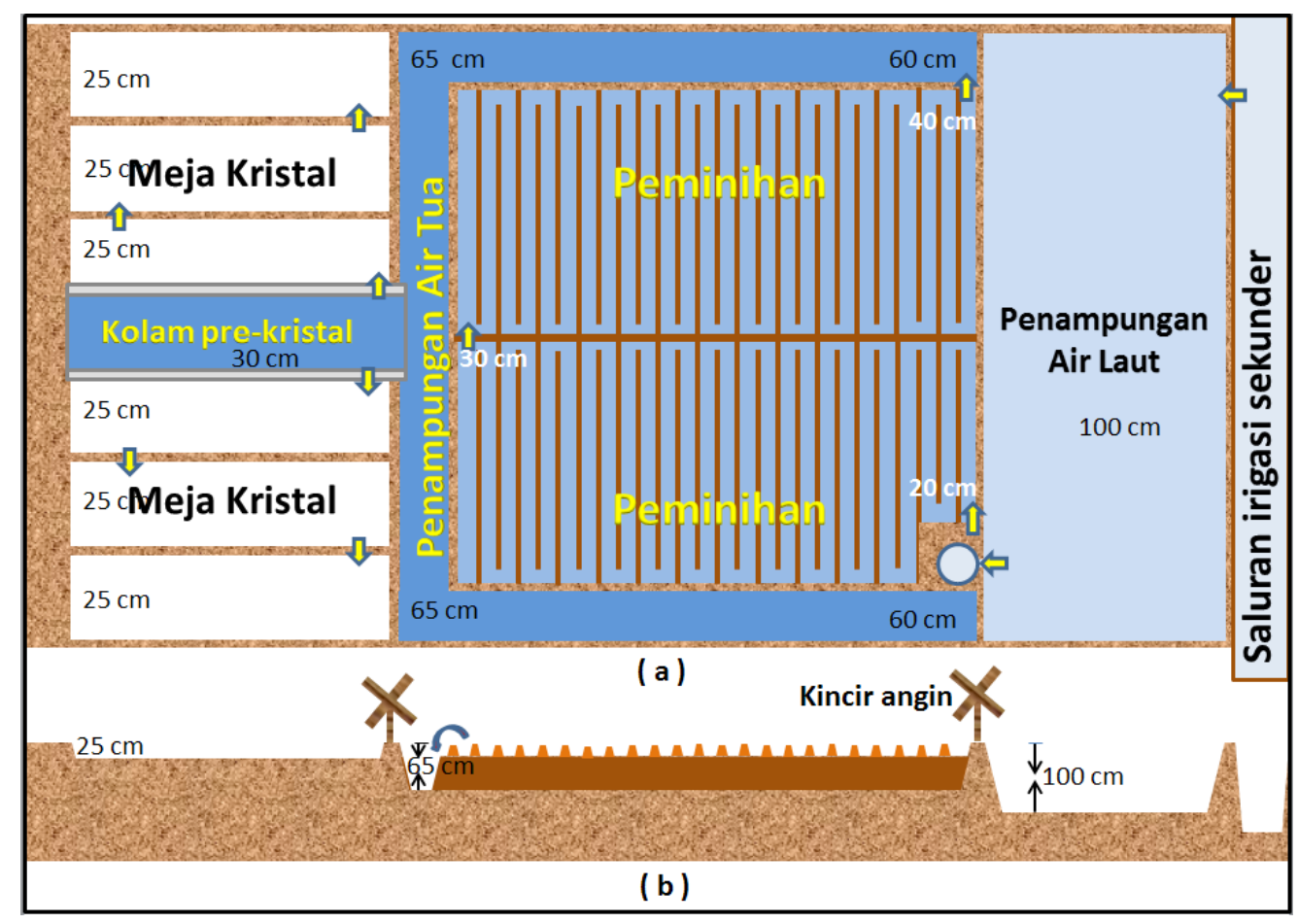

Gambar 6. Rekonstruksi tambak TUF yang disederhanakan dalam bentuk layout (a) dan potongan melintang (b). 

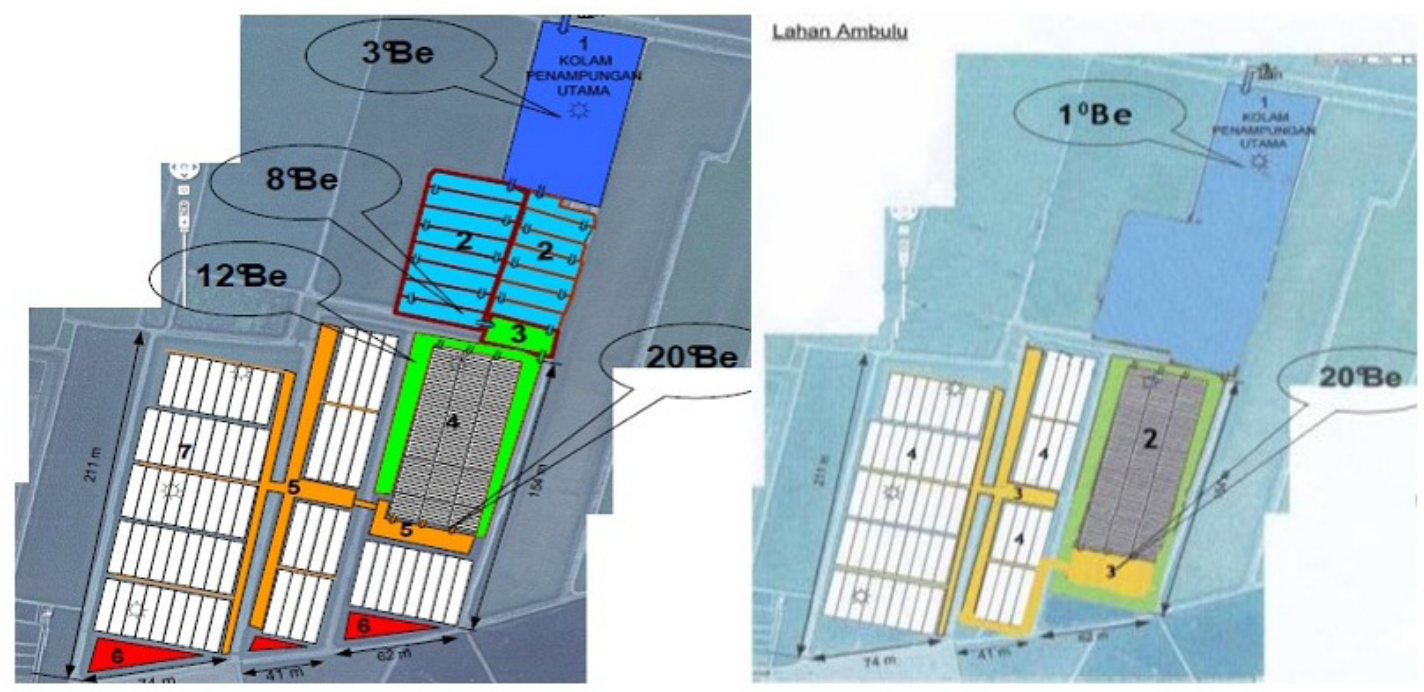

Gambar 7. Penggunaan kolam ulir bertahap besar \& kecil (kiri) dan hanya ulir kecil (kanan) pada sistem TUF (Dokumentasi diperoleh dari Ditjen KP3K dan Sanusi melalui pertemuan dan komunikasi langsung).

$\mathrm{m}^{2}$ atau sekitar $135 \%$ (Tabel 3).

Penggunaan ulir besar ataupun ulir kecil dapat disesuaikan dengan kondisi dan luas lahan. Jika ulir besar dan ulir kecil digunakan dalam suatu sistem TUF secara bersamaan, maka kemungkinan akan diperoleh presentase penambahan sebesar $247 \%$. Namun, bila hanya ulir kecil saja yang digunakan, didapat kenaikan luas bidang evaporasi sebesar $135 \%$. Penggunaan kolam ulir tersebut diduga berkontribusi terhadap percepatan ketersediaan brine yang siap dikristalkan $\left(20-25^{\circ} \mathrm{Be}\right)$, sehingga dapat meningkatkan kuantitas produksi dalam satu periode musim panen garam.

Perbandingan kuantitas produksi garam secara konvensional dan sistem TUF tersaji pada Tabel 4. Data yang dipergunakan adalah jumlah produksi dalam empat bulan masa panen pada tambak sistem TUF di Desa Ambulu Kecamatan Losari dan sistem konvensional di seluruh Desa Kanci Kulon Kec. Astanajapura, Desa Astanamukti Kec. Pangenan dan produksi lingkup Kabupaten Cirebon pada tahun 2012. Data pada Tabel 4 menunjukan bahwa produktivitas lahan menggunakan sistem TUF lebih tinggi dibandingkan menggunakan cara konvensional. Peningkatan produktivitas tambak sistem TUF mencapai $84 \%$ dibandingkan dengan Desa Kanci
Kulon yang memiliki produktitvitas rata-rata tertinggi di Kabupaten Cirebon, bahkan peningkatannya mencapai $112 \%$ jika dibandingkan produktivitas rata-rata cara konvensional di seluruh Kabupaten Cirebon.

\section{Proses radiasi dan konveksi pada tambak garam TUF}

Secara umum diketahui bahwa dari total seluruh radiasi matahari yang sampai ke bumi, sebanyak \pm $30-34 \%$ direfleksikan kembali ke atmosfer, $\pm 19 \%$ diabsorbsi oleh atmosfer, dan $\pm 47-51 \%$ diabsorbsi oleh bumi (Tjasyono, 2006 \& Panjaitan, 2011). Radiasi matahari merupakan salah satu faktor penting dalam proses evaporasi di tambak garam. Menurut Panjaitan (2011) nilai albedo mempengaruhi intensitas matahari: nilai yang kecil akan memberikan intensitas radiasi matahari yang besar, sebaliknya nilai albedo yang besar akan memberikan intensitas radiasi matahari yang kecil. Nilai albedo merupakan nilai perbandingan antara sinar matahari yang tiba di permukaan bumi dan yang dipantulkan kembali ke angkasa. Umumnya nilai albedo kecil terlihat pada musim kemarau. Intensitas radiasi matahari yang sampai ke tanah disimpan dalam bentuk energi panas (kalor). Panas yang terserap ini dimanfaatkan untuk membantu mempercepat penuaan air laut pada kolam kondenser dengan ketinggian air

Tabel 3. Perbandingan luas penampang tambak konvensional dengan luas penampang tambak TUF

\begin{tabular}{llll}
\hline Jenis Kolam & $\begin{array}{l}\text { luas penampang kolam } \\
\text { peminihan konvensional }\left(\mathrm{m}^{2}\right)\end{array}$ & $\begin{array}{l}\text { luas penampang kolam } \\
\text { peminihan TUF }\left(\mathrm{m}^{2}\right)\end{array}$ & $\begin{array}{l}\text { persentase penambahan } \\
\text { luas }(\%)\end{array}$ \\
\hline Ulir Besar A & 3.701 & 4.140 & 112 \\
Ulir Besar B & 2.335 & 2.606 & 112 \\
Ulir Kecil & 6.462 & 8.750 & 135 \\
\hline
\end{tabular}


yang relatif dangkal $(5-7 \mathrm{~cm})$.

Suhu tanah merupakan hasil dari keseluruhan radiasi yang merupakan kombinasi emisi panjang gelombang dan aliran panas dalam tanah (Lubis, 2007). Hasil pengukuran suhu udara, air (brine) dan tanah di meja peminihan selama 30 jam menunjukkan bahwa fluktuasisuhu tanah cenderung lebih stabil dibandingkan suhu udara (Gambar 8.), hal ini disebabkan sifat tanah yang lebih cepat dalam menyerap dan melepaskan kalor. Pada saat menjelang siang, siang dan sore hari, suhu tanah relatif lebih rendah dibandingkan suhu udara, sedangkan pada malam hari suhu tanah lebih hangat. Hasil pengukuran ini sesuai dengan Panjaitan \& Setiawan (2007) yang menyebutkan suhu tanah ratarata lebih besar daripada suhu atmosfer sekelilingnya karena panas spesifik tanah lebih kecil daripada udara sehingga penyimpanan panas di dalam tanah lebih lama.

Gambar 8 juga memperlihatkan bahwa suhu brine berfluktuasi cukup tajam hampir serupa pola dengan pola suhu udara. Kondisi ini lazim terjadi pada perairan sangat dangkal. Suhu air dan udara cepat meningkat saat penetrasi cahaya matahari mencapai dasar perairan dan suhu kembali turun saat sore hingga dini hari. Ketebalan kolom air yang rendah di kolam ulir $(7-10 \mathrm{~cm})$ dan transfer kalor dari tanah ke brine melalui proses konveksi diduga dapat membantu mempercepat peningkatan suhu brine pada pagi hari. Hal tersebut dikarenakan terdapat banyaknya pematang-pematang yang menyerap dan melepaskan energi kalor yang diperoleh dari radiasi matahari.

Proses pengaliran air tua (brine) dari kolam penampungan ke kolam ulir dilakukan pada pukul 10.00-14.00 WIB dimana pada rentang waktu tersebut efektifitas radiasi matahari mencapai permukaan bumi paling tinggi. Saat elevasi matahari tinggi, sinar matahari jatuh secara tegak lurus terhadap bumi sehingga luas bidang yang tersinari akan lebih sempit daripada ketika sinar jatuh secara miring. Intensitas radiasi yang diterima bumi (insolasi) berbanding terbalik dengan luas bidang yang tersinari membuat insolasi akan lebih kuat pada elevasi matahari tinggi (Tjasyono, 2006). Sebaliknya energi radiasi yang diterima bumi akan lemah pada elevasi matahari dengan sudut miring dikarenakan tebalnya lapisan atmosfer dan lebih banyaknya sinar yang dipantulkan kembali (Wallace, 1995).

Tabel 4.

Perbandingan produksi dan produktivitas menggunakan sistem TUF dan konvensional di Kabupaten Cirebon

\begin{tabular}{lllll}
\hline Lokasi (lingkup) & $\begin{array}{l}\text { Sistem } \\
\text { produksi }\end{array}$ & $\begin{array}{l}\text { Jumlah } \\
\text { produksi (ton) }\end{array}$ & $\begin{array}{l}\text { Luas } \\
\text { lahan (ha) }\end{array}$ & $\begin{array}{l}\text { Produktivitas } \\
\text { (ton/ha/musim) }\end{array}$ \\
\hline Desa Ambulu, Losari & TUF & 1.000 & 4,8 & 208 \\
Desa. Kanci Kulon Kec. Astanajapura & Konvensional & 27.255 & 222 & 113 \\
Desa Astanamukti Kec Pangenan & Konvensional & 150.052 & 1.514 & 99 \\
Kab. Cirebon & Konvensional & 262.231 & 2.680 & 98 \\
\hline
\end{tabular}

Sumber: Dinas KP Kab. Cirebon dan data primer

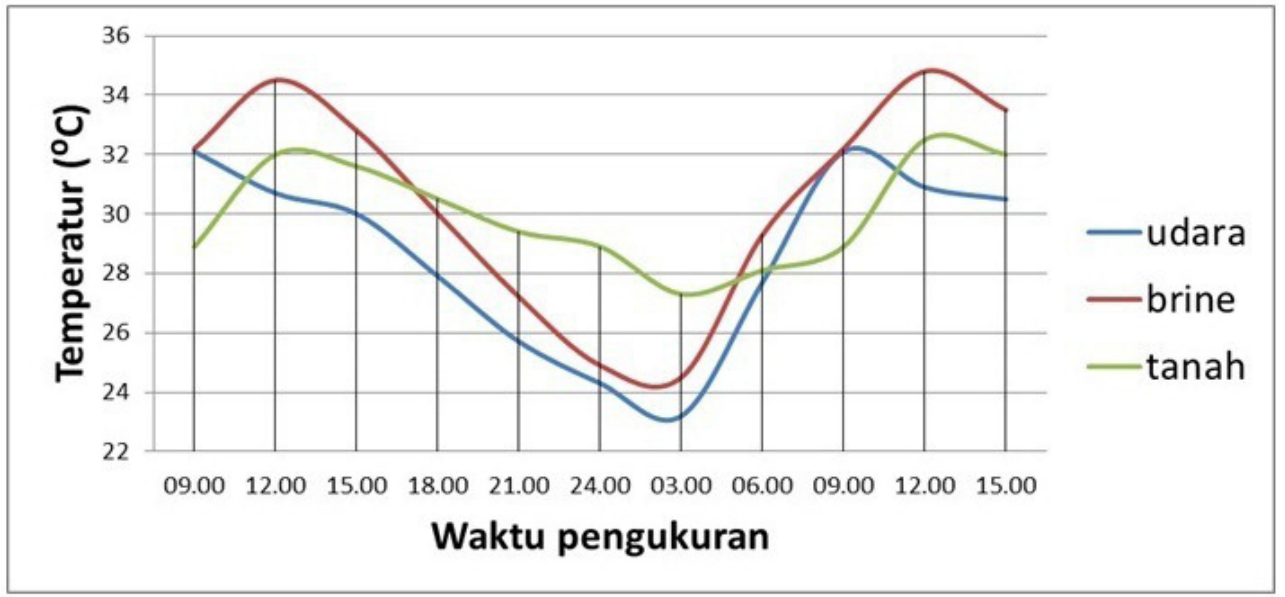

Gambar 8. Perbandingan suhu udara, brine dan tanah (sisi pematang) di kolam ulir. 


\section{KESIMPULAN}

Teknologi Ulir pada TUF menekankan modifikasi lahan tambak dimana petakan-petakan dibuat memanjang dan berseri dalam satu kolam kondenser (ulir) dan kolam reservoir diperdalam. Modifikasi tersebut memudahkan petambakdalammengendalikan aliran brine dan memantau kenaikan densitas brine. Perubahan desain pada kolam kondenser dengan menambah pematang menunjukkan penambahan luas penampang bidang yang akan terdedah radiasi matahari, yaitu $112 \%$ untuk ulir besar dan $135 \%$ untuk ulir kecil. Tanah pematang pada petakan ulir merupakan konduktor panas yang dapat mentransfer kalor ke brine, sehingga membantu mempercepat evaporasi. Modifikasi lahan juga meningkatkan efisensi pemanfaatan lahan pada kolam reservoir dari $28 \%$ terhadap total luas tambak menjadi $75 \%$ terhadap total volume tambak yang dapat meningkatkan produksi garam sebesar 200 ton/ha/musim. Secara umum dapat disimpulkan bahwa perubahan desain dan tata letak lahan pada modifikasi lahan tambak garam dapat meningkatkan produksi garam hingga mencapai \pm 200 ton/ha/musim panen.

\section{PERSANTUNAN}

Peneltian ini merupakan bagian dari Kajian Revitaliasi Tata Kelola Tambak dalam Kerangka Penerapan Ekonomi Biru pada Pusat Peneltian dan Pengembangan Sumberdaya Laut dan Pesisir Balitbang Kelautan dan Perikanan, Kementerian Kelautan dan Perikanan, yang didanai oleh APBN DIPA P3SDLP TA 2014. Ucapan terima kasih disampaikan kepada Dr. Budi Sulistiyo selaku Kepala P3SDLP, Sekretariat program PUGAR, Dr Hartanta Tarigan dan Drs. Amiril, M.Si atas masukan dan arahannya. Terima kasih juga diucapkan kepada Bapak Sanusi, Bapak Boni Hasanudin dan Wahyu Hidayat atas kerjasamanya sehingga penelitian ini dapat terlaksana dengan baik.

\section{DAFTAR PUSTAKA}

Adiyoso, R., Darmawan, R., Kadir, A. \& Nugroho, H. (2014). Perencanaan Sistem Jaringan Tambak Garam di Pemongkong Kabupaten Lombok Timur. Jurnal Karya Teknik Sipil UNDIP, Vol. 3, hal $11-23$

Baert, P., Bosteels, T. \& Sorgeloos, P. (2000). Manual on the Production and Use of Live Food for Aquaculture : 4.5. Pond Production. FAO Corporate Document Repository. Laboratory of Aquaculture \& Artemia Reference Center University of Gent, Belgium

Bramawanto, R., Suhelmi, I.R., Prihatno, H., Sagala,
S.L., Triwibowo, H., Suryono, D.D. \& Sudirman, N. (2014). Revitalisasi Tata Kelola Tambak Garam dalam Kerangka Penerapan Ekonomi Biru pada Industri Garam Rakyat. Laporan Akhir Penelitian. Pusat Penelitian dan Pengembangan Sumber Daya Laut dan Pesisir. Balitbang Kelautan dan Perikanan - KKP. 100 hal.

Departemen Perindustrian. (2009). Buku VI Peta Panduan (Road Map) Pengembangan Klaster Industri Prioritas Industri Kecil dan Menengah Tertentu 2010-2014: hlm 31-62

Direktorat Jenderal KP3K-KKP. (2014). Kebangkitan PUGAR Mewujudkan Garam Industri. http:// pdpt.kp3k.kkp.go.id/index.php/arsip/c/137/ Kebangkitan-PUGAR-Mewujudkan-GaramIndustri/?category_id=20. Diunduh tanggal 9 November 2014.

Kadarwati U., Ratnawati, H.I., Prabawa, F.Y., Hidayat, W., Hendrajana, B. \& Dewi, L.C. (2010). Studi Potensi Bittern Pada Tambak Garam Rakyat. Laporan Akhir Penelitian. Pusat Penelitian dan Pengembangan Sumberdaya Laut dan Peissir. Balitbang KP- KKP.

Kementerian Kelautan dan Perikanan. (2014). Siaran Pers: KKP Perkuat Basis Produksi Garam Rakyat. http://www.kkp.go.id/index.php/arsip/c/10496/ KKP-Perkuat-Basis-Produksi-Garam-Rakyat/. Diunduh tanggal 7 Oktober 2014.

Kurniawan T. \& Erlina, M.D. (2012). Peningkatan Produksi Garam Melalui PenerapanTeknologi Ulir-Filter (TUF) di Kabupaten Cirebon Jawa Barat. Makalah Seminar Nasional Inovasi Teknologi Pengolahan Produk dan Bioteknologi Kelautan dan Perikanan IV. Jakarta.

Lubis, K. S. (2007). Aplikasi Suhu dan Aliran Panas Tanah. USU Repository. Medan.

Panjaitan, A. L. (2011). Estimasi Energi Radiasi Matahari Bulanan dan Tahunan dengan Model Solar Energy-Air Temperature. Institut Teknologi Bandung. Bandung

Panjaitan T. \& Setyawan, N. (2007). Sifat Thermal Tanah Pasiran Pantai dengan Pemberian Bahan Pengkondisi Tanah dan Biomikro Pada Budidaya Tanaman Cabai (Capsicum Annuum, L). Jurnal Agritech, Vol. 27, No. 3, hal 137-146.

Purbani, D. (2001). Proses Pembentukan Kristalisasi Garam. Pusat RisetWilayah Laut dan Sumberdaya Nonhayati, Badan Riset Kelautan dan Perikanan Departemen Kelautandan Perikanan. 
Sekretariat Pugar. (2012). Laporan Akhir Pemberdayaan Usaha Garam Rakyat Tahun 2012. Direktorat Jenderal Kelautan, Pesisir dan Pulau-pulau Kecil, Kementerian Kelautan dan Perikanan.

Sekretariat Pugar. (2013). Laporan Akhir Pemberdayaan Usaha Garam Rakyat Tahun 2013. Direktorat Jenderal Kelautan, Pesisir dan Pulau-pulau Kecil, Kementerian Kelautan dan Perikanan.

Tjasyono, B. (2006). Ilmu Kebumian dan Antariksa, Rosdakarya, Bandung.

Wallace, J.S. (1995). Calculating evaporation: resistance to factors. Agricultural and Forest Meteorology 73, p. 353-366. 